\title{
PRODUKSI DAN KUALITAS VIRGIN COCONUT OIL (VCO) DI DESA DALANG DAN GADUNG SARI, KECAMATAN SELEMADEG TIMUR, KABUPATEN TABANAN
}

\author{
I N. Ardika ${ }^{1}$ dan N. N. Darmiati ${ }^{2}$
}

\begin{abstract}
ABSTRAK
Kegiatan pengabdian kepada masyarakat ini bertujuan untuk memproduksi dan menganalisa kualitas virgin coconut oil (VCO) di desa Dalang dan Gadung Sari Kecamatan Selemadeg Timur Kabupaten Tabanan. Metode yang diterapkan dalam pemberdayaan masyarakat pada kegiatan Program Kemitraan Wilayah (PKW) ini adalah: (1) Koordinasi dan komunikasi secara partisipasif dengan kelompok wanita tani (KWT) pembuat VCO untuk merumuskan program mulai dari perencanaan, operasional dan evaluasi; (2) Penyuluhan untuk membangun persepsi dan pemahaman masyarakat mengenai inovasi program yang diterapkan; (3) Bimbingan dan Pelatihan mengenai terapan ipteks yang diaplikasi bagi masyarakat; (4) Pendampingan yaitu pertemuan secara berkala dan berkelanjutan antara pendamping dengan masyarakat sasaran hingga ipteks yang diaplikasikankan dapat dilaksanakan secara tepat. Hasil pengabdian menunjukkan bahwa untuk menghasilkan satu liter VCO dibutuhkan kelapa yang sudah matang antara 10-15 butir. Hasil analisis laboratorium menunjukkan bahwa komposisi asam lemak VCO di desa Dalang dan Gadung Sari telah sesuai dengan standard APCC (Asian and Pacific Coconut Community), kecuali kadar air sedikit lebih tinggi.
\end{abstract}

Kata kunci : kelapa, VCO, kualitas, kelompok wanita tani (KWT)

\begin{abstract}
This community service activity aims to produce and analyze the quality of virgin coconut oil (VCO) in Dalang and Gadung Sari village, Subdistrick of Selemadeg Timur, Tabanan regency. The methods applied in community empowerment in this Partnership Region Program (PKW) are: (1) Participatory coordination and communication with farmer group of women (KWT) VCO makers to formulate programs ranging from planning, operation and evaluation; (2) Counseling to build community perceptions and understanding on program innovation; (3) Guidance and Training on applied science and technology applied to the community; (4) Assistance is a regular and ongoing meeting between the assistant and the target community until the applied science and technology can be implemented appropriately. The results of devotion show that to produce one liter of VCO is needed that between 10-15 grains. The results of laboratory analysis showed that the fatty acid composition of VCO in Dalang and Gadung Sari villages was in accordance with the standard of APCC (Asian and Pacific Coconut Community), except the water content was slightly higher.
\end{abstract}

Keywords : coconut, VCO, quality, farm women group (KWT)

\footnotetext{
${ }^{1}$ Staf Pengajar Fakultas Peternakan Universitas Udayana, ardika@unud.ac.id

${ }^{2}$ Staf Pengajar Fakultas Pertanian Universitas Udayana
} 


\section{PENDAHULUAN}

Struktur penduduk menurut mata pencaharian di Desa Dalang dan Gadung Sari Kecamatan Selemadeg Timur Kabupaten Tabanan menunjukkan bahwa sebagian besar penduduk menggantungkan sumber kehidupannya di sektor pertanian (82\%), sektor lain yang menonjol dalam penyerapan tenaga kerja adalah perdagangan (4.\%), sektor industri rumah tangga dan pengolahan ( $2,3 \%)$, sektor jasa $(0,8 \%)$ dan sektor lainnya seperti pegawai negeri, karyawan swata dari berbagai sektor $(1,6 \%)$. Angka tersebut mengindikasikan bahwa sektor pertanian merupakan bidang startegis sehingga perlu medapatkan prioritas.

Dalam Rencana Pembangunan Jangka Menengah Kabupaten Tabanan tahun 2006-2011 Kecamatan Selemadeg Timur tepatnya di wilayah Desa Dalang dan Desa Gadung Sari dikembangkan sebagai kawasan agropolitan. Sementara dari subsektor perkebunan, komoditas yang paling banyak diusahakan adalah kelapa yang mencapai 422 ha dengan produksi mencapai 5.250 ton/tahun. Produksi kelapa yang cukup besar di wilayah ini sebagian besar dijual dalam bentuk kelapa butiran sehingga tidak memberikan keuntungan yang memadai bagi petani. Pengembangan usaha pengolahan kelapa akan dapat membantu meningkatkan pendapatan petani dari subsektor perkebunan. Salah satu yang dapat dilakukan adalah dengan alih teknologi pembuatan minyak VCO (virgin coconut oil) yang mulai banyak diminati petani karena harganya yang mahal dengan pasar yang cukup luas untuk tujuan ekspor. Kendala yang dihadapi adalah lemahnya penguasaan teknologi petani untuk memproduksi minyak VCO sesuai standar kualitas yang diinginkan.

Virgin coconut oil (VCO), menurut APCC (Asian and Pacific Coconut Community) adalah minyak yang didapatkan dari daging buah kelapa yang segar yang berasal dari kelapa yang tua, diproses dengan cara mekanis dan secara alami, dengan tanpa atau menggunakan panas, yang tidak menyebabkan perubahan kandungan pada minyak. VCO dapat dimanfaatkan untuk keperluan pangan seperti minyak goreng, bahan margarin, dan mentega putih. Asy'ari dan Cahyono (2006) menambahkan bahwa untuk mendapatkan manfaat bagi kesehatan, VCO bisa dikonsumsi secara langsung ataupun digunakan untuk menggoreng atau menumis makanan. Dengan struktur kimia asam lemak jenuh yang tidak memiliki double bond, VCO relatif tahan terhadap panas, cahaya, dan oksigen single sehingga memiliki daya simpan lama.

VCO memiliki nilai bilangan asam, free fatty acid (FFA), angka tak tersaponifikasi, dan bilangan peroksida yang lebih rendah dibandingkan minyak kelapa biasa. Nilai bilangan asam, FFA, angka tak tersaponifikasi, dan bilangan peroksida VCO yang rendah menunjukkan bahwa produk ini lebih tahan terhadap ketengikan dibandingkan minyak kelapa biasa. Kualitas VCO sangat tergantung pada stabilitas penyimpanan, pemasakan, karakteristik penggorengan, serta perangkat fisik dan nutrisinya. Pontoh et al. (2008) menyatakan bahwa kualitas VCO dengan metode pemanasan bertahap menghasilkan kadar minyak 14,38 \%, kadar air 0,0706 \%, asam lemak bebas $0,1171 \%$ dan bilangan peroksida 0,2278 . Metode pemancingan minyak menghasilkan kadar minyak 15,27 $\%$, kadar air $0,1566 \%$, asam lemak bebas $0,1744 \%$ dan bilangan peroksida 0,3545 . Metode fermentasi menghasilkan kadar minyak 13,97 \%, kadar air 0,1333\%, asam lemak bebas 0,3671 \% dan bilangan peroksida 0,2148. Berdasarkan kandungan kadar minyak, kadar air, asam lemak bebas dan bilangan peroksida dari ketiga metode pembuatan VCO, maka metode pemanasan bertahap memberikan hasil yang lebih baik diikuti oleh metode pemancingan minyak. Metode fermentasi adalah metode yang kurang baik.

Berdasarkan uraian tersebut diatas, pengabdian kepada masyarakat ini bertujuan untuk mendampingi kelompok wanita tani (KWT) di desa Dalang dan Gadung Sari dalam memproduksi VCO dan menganalisis kualitas VCO yang dihasilkan. Dengan harapan bahwa dari hasil analisis ini KWT dapat meningkatkan pendapatannya melalui pembuatan VCO tersebut. 


\section{METODE PELAKSANAAN}

Metode

Metode yang diterapkan dalam pemberdayaan masyarakat pada kegiatan PKW ini adalah sebagai berikut: (1) Penyuluhan untuk membangun persepsi dan pemahaman masyarakat khususnya KWT di desa Dalang dan Gadung Sari mengenai inovasi atau program pembuatan VCO yang diterapkan, (2) Pelatihan mengenai terapan ipeks yang diaplikasi bagi masyarakat (KWT), dan (3) Pendampingan yaitu pertemuan secara berkala dan berkelanjutan antara pendamping dengan masyarakat (KWT) sasaran hingga ipteks pembuatan VCO yang diaplikasikan dapat dilaksanakan secara tepat oleh angota KWT. Data produksi dan kualitas VCO yang diperoleh dianalisa secara deskripsi.

Tahap Kegiatan

Pelaksananan kegiatan alih teknologi dalam memproduksi VCO sebagai berikut:

(1) Kordinasi dan komunikasi secara partisipasif dengan anggota KWT untuk merumuskan program mulai dari perencanaan, operasional dan evaluasi.

(2) Penyuluhan tentang pentingnya memproduksi VCO

(3) Pelatihan pengolahan pembuatan VCO dan analisis kualitas VCO.

(4) Proses pembuatan VCO adalah dengan metode tradisional sebagai berikut:

Kelapa diparut, kemudian diperas hingga menghasilkan santan. Santan yang diperoleh ditempatkan pada wadah yang bersih, steril dan transparan lalu didiamkan selama 1 jam hingga terbentuk krim santan. Pisahkan krim santan dari pelarut airnya dan tempatkan krim santan dalam wadah bertutup yang bersih, steril dan transparan. Kemudian diamkan selama 10-12 jam dalam kondisi wadah tertutup dan tempat yang kering. Pisahkan minyak VCO dari krim santan dengan metode penyedotan dengan selang kecil. VCO yang diperoleh disaring dengan menggunakan kertas saring yang bersih dan steril. Selanjutnya VCO dikirim ke Bogor untuk dianalisa.

\section{HASIL DAN PEMBAHASAN}

Kegiatan pengabdian kepada masyarakat ini dilaksanakan di Desa Dalang dan Gadung Sari Kecamatan Selemadeg Timur Kabupaten Tabanan Bali. Pendampingan dilaksanakan pada Kelompok Wanita Tani Nadi Sari Desa Dalang untuk memproduksi VCO. VCO dibuat dari kelapa yang sudah matang (gambar 1) dan jatuh sendiri dari pohonnya, kemudian disimpan selama satu minggu. VCO yang dihasilkan tersaji pada gambar 2. Jumlah kelapa dan VCO yang dihasilkan tersaji pada table 1. Hasil pengabdian menunjukkan bahwa untuk memproduksi satu liter VCO dibutuhkan kelapa antara 10-15 butir. Hal ini mengindikasikan bahwa ada pengaruh jumlah kelapa untuk menghasilkan VCO. Syarat-syarat kelapa untuk dijadikan VCO antara lain: 1) kulit kelapa berwarna coklat menandakan kelapa sudah cukup tua,2) apabila dikocok berbunyi nyaring yang menandakan bahwa air kelapa sudah berkurang. Hal ini bekaitan dengan dekomposisi kandungan gizi kelapa, 3) kelapa belum berkecambah, 4) bila dibelah, daging buah berwarna putih dengan ketebalan sekitar 10-15 mm, 5) umur pohon kelapa tidak terlalu muda atau terlalu tua. Disamping jumlah kelapa, faktor anggota KWT juga nampaknya berpengaruh terhadap hasil produksi VCO. VCO di KWT Nadi Sari dibuat secara tradisional, sudah barang tentu tergantung juga dari proses produksi yakni proses pemerasan kelapa menjadi santan. Santan yang diperoleh tergantung dari kekuatan pemerasan dari ibu-ibu KW, disamping pengalaman juga berpengaruh.

Hasil analisis laboratorium VCO di ICBB Bogor (table 2) menunjukkan kandungan asam lemak tertinggi adalah asam laurat yaitu sebesar 40,01\% di desa Gadung Sari dan 49,82\% di desa Dalang. Persentase asam laurat yang direkomendasikan oleh APCC adalah 43,0 - 53,0 \%. Kadar asam 
laurat minyak VCO di dua desa sudah memenuhi standar APCC. Hal ini disebabkan karena kelapa yang digunakan sudah tua dan berwarna coklat.

Tabel 1. Produksi VCO pada KWT Nadi Sari di Desa Dalang

\begin{tabular}{|c|c|c|}
\hline Anggota & Jumlah Kelapa (butir) & VCO yang dihasilkan (Liter) \\
\hline 1 & 25 & 2,0 \\
2 & 15 & 1,0 \\
3 & 15 & 1,0 \\
4 & 15 & 1,2 \\
5 & 10 & 1,0 \\
6 & 12 & 1,0 \\
7 & 15 & 1,0 \\
8 & 40 & 3,5 \\
9 & 50 & 5,0 \\
\hline
\end{tabular}

Hasil analisis laboratorium VCO di ICBB Bogor (table 2) menunjukkan kandungan asam lemak tertinggi adalah asam laurat yaitu sebesar 40,01\% di desa Gadung Sari dan 49,82\% di desa Dalang. Persentase asam laurat yang direkomendasikan oleh APCC adalah 43,0 - 53,0 \%. Kadar asam laurat minyak VCO di dua desa sudah memenuhi standar APCC. Hal ini disebabkan karena kelapa yang digunakan sudah tua dan berwarna coklat.

Menurut Asy'ari dan Cahyono (2006) kandungan asam lemak rantai jenuh terutama yang berantai pendek sampai sedang (seperti asam laurat) disinyalir akan meningkatkan kualitas dari minyak VCO. Hal ini berkaitan dengan semakin mudahnya jenis asam lemak tersebut untuk ditranspor di dalam darah dan akan segera diubah menjadi energi setelah masuk ke dalam sel. Sehingga kandungan asam tersebut yang tinggi di dalam minyak VCO akan meningkatkan kualitas terutama berkaitan dengan sumber energi dan meningkatkan vitalitas bagi tubuh. Sebagian besar asam lemak penyusun minyak VCO hasil cek lab ini adalah asam lemak berantai pendek yaitu $70 \%$ sudah sesuai dengan standar APCC yaitu asam oleat 5-10\% dan linoleat 1-2,5\% (Tabel 2). Sehingga pantaslah kalau minyak VCO memiliki banyak manfaat terutama berkaitan dengan kesehatan tubuh. Asam lemak tak jenuh (Unsaturated Fatty Acid $=U F A$ ) seperti asam oleat dan linoleat memang terbukti mampu menurunkan kadar kolesterol tubuh. Ditambahkan pula oleh Kristi et al. (2012) kedua asam lemak tersebut merupakan asam lemak rantai sedang yang berfungsi menyembuhkan berbagai penyakit. Selanjutnya dinyatakan bahwa di dalam tubuh manusia, asam laurat diubah menjadi monolaurin yang berfungsi menghambat dan membunuh berbagai virus, bakteri dan protozoa. Asam lemak lainnya seperti asam kaprat, kaplirat berperan dalam pembakaran nutrisi makanan menjadi energi. Asam kaprat di dalam tubuh diubah menjadi monocaprin yang bermanfaat untuk menyembuhkan beragam penyakit kelamin, seperti Herpes Simplex Virus-2 (HSV-2) dan HIV-1.

Tabel 2. Hasil Uji Kualitas VCO di Desa Dalang dan Gadung Sari Kec. Selemadeg Timur Kab. Tabanan

\begin{tabular}{|l|c|c|c|}
\hline Hasil Uji & Desa Dalang* & Desa Gadung Sari* & Standar** \\
\hline Asam Kaprilat (\%) & 4,28 & 3,24 & $5-10$ \\
Asam Kaprat & 4,35 & 3,51 & $4,5-8$ \\
Asam Laurat & 49,82 & 40,01 & $43-53$ \\
Asam Miristat & 21,23 & 19,55 & $16-21$ \\
Asam Palmitat & 16,17 & 18,21 & $7,5-10$ \\
Asam Stearat & 0,52 & 0,5 & $2-4$ \\
Asam Oleat & 7.77 & 12,45 & $5-10$ \\
Asam Linoleat & 1,55 & 2,5 & $1-2,5$ \\
Asam Linolenat & 0,02 & 0,05 & $<0,5$ \\
Kadar air & 0,33 & 1,03 & $<0,1$ \\
\hline
\end{tabular}

*Data hasil analisa lab VCO di ICBB Bogor

**Standar APCC (Asian and Pacific Coconut Community) dalam Asy'ari dan Cahyono (2006) 
Hasil analisa laboratorium kadar air VCO di desa Dalang dan Gadung Sari masing-masing 1,03 dan $0,33 \%$ (tabel 2). Hal ini menunjukkan bahwa kadar air dalam minyak VCO lebih tinggi dari standar, yang berarti kualitas minyak VCO adalah masih rendah. Kadar air yang tinggi bisa dikarenakan bercampurnya air pada saat pembuatan dan tidak bisa dipisahkan dengan penyaringan biasa. Kadar air yang tinggi dalam minyak VCO akan menjadi media yang baik untuk reaksi-reaksi kimia, seperti reaksi redoks dan enzimatis maupun aktivitas mikroorganisme yang cenderung merusak minyak VCO itu sendiri (Asy'ari dan Cahyono, 2006). Penentuan kadar air dalam minyak sangat penting dilakukan karena adanya air dalam minyak akan mengakibatkan reaksi hidrolisis yang dapat menyebabkan minyak menjadi tengik. Hal ini terjadi karena adanya asam lemak bebas yang dihasilkan dalam reaksi hidrolisis (Sri Mulyani et al., 2010). Reaksi hidrolisi terutama terjadi pada minyak yang mengandung asam lemak jenuh berantai pendek seperti asam butirat, asam valerat, asam kaproat dan ester alifatik seperti metal nonil keton. Adanya air didalam minyak juga tidak dikehendaki karena merupakan medium yang baik bagi mikroorganisme untuk merusak minyak dan sangat berpengaruh terhadap daya simpan minyak. Makin banyak air yang dikandung dalam minyak, minyak tersebut akan mudah rusak. Menurut Sulistyo et al. (2009) dikutip oleh Anwar dan Salima (2016), semakin tinggi kadar air maka akan semakin cepat tengik. Disamping itu, protein yang masih tersisa juga dapat memicu ketengikan bila melebihi ambang batas $0,5 \%$. Untuk melihat masih tersisanya protein dalam VCO dapat dengan cara diendapkan terlebih dahulu, sehingga akan terlihat adanya butiran kecil, halus, dan putih. Itu berarti protein yang mengendap akibat penyaringan yang tidak sempurna. Protein merupakan sarana mikroba untuk tumbuh sehingga menyebabkan ketengikan.

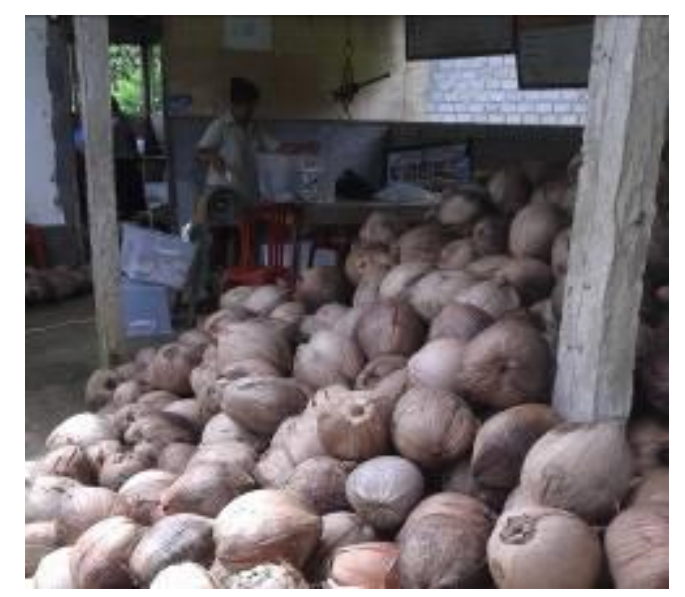

Gambar 1. Bahan Baku Kelapa

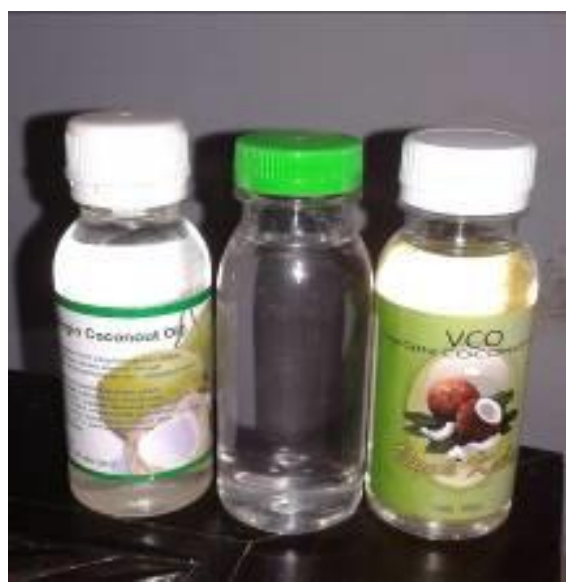

Gambar 2. Virgin coconut oil (VCO)

\section{KESIMPULAN DAN SARAN}

Kesimpulan

Dari hasil pengabdian kepada masyarakat ini dapat disimpulkan bahwa:

1. Untuk menghasilkan satu liter virgin coconut oil (VCO) diperlukan kelapa yang sudah tua dan berwana coklat sebanyak $10-12$ butir.

2. Kualitas VCO di desa Dalang dan Gadung Sari telah memenuhi standar Asian and Pacific Coconut Community (APCC) kecuali kadar airnya masih tinggi. 
Saran

Untuk menurunkan kadar air yang terkandung dalam VCO perlu pendampingan lebih lanjut terutama dalam proses penyaringan VCO.

\section{UCAPAN TERIMA KASIH}

Penulis menyampaikan terima kasih yang sebesar-besarnya kepada Direktorat Riset dan Pengabdian pada Masyarakat Kemenristek Dikti atas dana yang diberikan, Ketua Lembaga Pengabdian kepada Masyarakat Universitas Udayana serta Kelompok Wanita Tani (KWT) desa Dalang dan Gadung Sari Kecamatan Selemadeg Timur Kabupaten Tabanan yang telah membantu kelancaran kegiatan ini.

\section{DAFTAR PUSTAKA}

Anwar, C. dan R. Salima. 2016. Perubahan rendemen dan mutu virgin coconut oil (VCO) pada berbagai kecepatan putar dan lama waktu sentrifugasi. Jurnal Teknotan 10(2):51-60.

Asy,ari, M. dan B. Cahyono. 2006. Pra standarisasi produksi dan virgin coconut oil. JSKA. IX (3): 1-9.

Kristi, J., N. Handayani, dan A. Yuniati. 2012. Pengaruh kualitas VCO ( Virgin Coconut Oil) terhadap nilai konstanta Keer dan perubahan sudut polarisasi cahaya. Prosiding Pertemuan dan Presentasi IlmiahPenelitian Dasar Ilmu Pengetahuan dan Teknologi Nuklir. Pusat Teknologi Akselertor dan Proses Bahan - BATAN, Yogyakarta. Hal. 28-34.

Pontoh, J. M.Br. Surbakti dan M. Papilaya. 2008. Kualitas virgin coconut oil dari beberapa metode pembuatan. Chem. Prog. 1(1):60-65.

Sri Mulyani, I. Inawati, E. Susilawati, dan A.C. Suputro. 2010. Pengaruh lama waktu pemeraman buah kelapa setelah dipanen terhadap kualitas virgin coconut oil. ISBN:979-498-547-3. Hal. 457-463. 